\title{
A classification of associative strategies in paired-associate learning ${ }^{1,2}$
}

\author{
CLESSEN J. MARTIN, MICHIGAN STATE UNIVERSITY \\ FREDERICK J. BOERSMA, UNIVERSITY OF ALBERTA, EDMONTON
}

DAVID L. COX, MICHIGAN STATE UNIVERSITY

\begin{abstract}
Although verbal reports are highly idiosyncratic, the results of these two studies show that it was possible to categorize them in a reliable and systematic manner. More specifically, a seven category strategy classification scheme was developed which permitted the categories to be rank ordered along an apparent continuum of cue complexity. Experiment I revealed a statistically significant increasing monotonic relationship between level of strategy employed and performance on the learning task. Similar findings were obtained in a replication of this experiment.
\end{abstract}

\section{Problem}

Although the simplest way to find out how a person has learned a task is to ask him, most investigators do not question Ss about such matters, and such questioning is seldom done systematically. The appropriateness of asking people what they did while attempting to master a task has been discussed by Miller, Galanter, \& Pribram (1960). And recently, several studies have shown that a significant portion of the variance in the learning task can be accounted for on the basis of Ss' verbal reports (Farber, 1963; Eagle \& Leiter, 1964; Underwood \& Schulz, 1960).

Experiment I was undertaken to develop a systematic and reliable procedure for analyzing and classifying verbal reports obtained at the conclusion of a pairedassociate learning task. It was believed that these reports would provide important data concerning the relationship between types of cues employed during the learning task and rate of acquisition. Experiment II merely served as a replication of experiment $I$,

\section{Method}

\section{Experiment I}

Thirty-nine advanced educational psychology students served as Ss in the experiment. They were presented, in a group, a paired-associate learning task consisting of eight pairs of low meaningful (M) paralogs selected from Noble's (1952) list: Meardon-Zumap, SagrolePolef, Rennet-Quipson, Volvap-Nares, Neglan-Gokem, Tarop-Gojey, Latuk-Brugen, Bodkin-Nostaw.

The items were placed on Thermofax transparencies and presented on an overhead projector in different random orders, for both learning and test trials. Ten learning and 10 test trials were presented at a $3 \mathrm{sec}$. rate for the learning trials, and at a $4 \mathrm{sec}$. rate for the test trials. A recognition procedure was employed for the test trials with each stimulus being presented with all eight responses. The responses on the test transparencies were randomized to avoid any serial position effect, and Ss were provided with test booklets
TABLE I

Classification of Associative Strategies

\begin{tabular}{|c|c|c|}
\hline Category Level & $\begin{array}{l}\text { Type of Cue Subject } \\
\text { Reported Using }\end{array}$ & $\begin{array}{l}\text { Example of Verbal } \\
\text { Report }\end{array}$ \\
\hline $\begin{array}{l}\text { 1. No Reported } \\
\text { Associations }\end{array}$ & $\begin{array}{l}\text { S was not able to state } \\
\text { how he managed to make } \\
\text { the association. }\end{array}$ & $\begin{array}{l}\text { Sagrole-Polef: "Don't } \\
\text { know how I learned } \\
\text { this pair." }\end{array}$ \\
\hline 2. Repetition & $\begin{array}{l}\text { S reported rehearsing } \\
\text { the pair. }\end{array}$ & $\begin{array}{l}\text { Volvap-Nares: "Just } \\
\text { kept repeating these } \\
\text { words to myself." }\end{array}$ \\
\hline $\begin{array}{l}\text { 3. Single Letter } \\
\text { Cues }\end{array}$ & $\begin{array}{l}\text { S reported using a single } \\
\text { letter in each of the } \\
\text { paralogs in making the } \\
\text { association. }\end{array}$ & $\begin{array}{l}\text { Tarop-Goiey: "Noticed } \\
\text { that each word con- } \\
\text { tained an O." }\end{array}$ \\
\hline $\begin{array}{l}\text { 4. Mulriple Letter } \\
\text { Cues }\end{array}$ & $\begin{array}{l}\text { S reported using multiple } \\
\text { letters in each of the } \\
\text { paralogs. }\end{array}$ & $\begin{array}{l}\text { Sagrole-Polef: "Each } \\
\text { word contains an } \\
\text { OLE." }\end{array}$ \\
\hline $\begin{array}{l}\text { 5. Word Forma- } \\
\text { tion }\end{array}$ & $\begin{array}{l}\text { S reported that an actual } \\
\text { word was embedded in } \\
\text { one or both of the para- } \\
\text { logs and made use of } \\
\text { these words in making } \\
\text { the association. }\end{array}$ & $\begin{array}{l}\text { Meardon-Zumap: "The } \\
\text { word EAR is con- } \\
\text { tained in meardon } \\
\text { and learned that } \\
\text { EAR goes with } \\
\text { Zumap." }\end{array}$ \\
\hline 6. Superordinate & $\begin{array}{l}\text { S reported selecting } \\
\text { elements from each of } \\
\text { the two paralogs that } \\
\text { had some relationship to } \\
\text { each other. }\end{array}$ & $\begin{array}{l}\text { Sagrole-Polef: "Sag- } \\
\text { role begins with S } \\
\text { and Polef with P, } \\
\text { thought of State } \\
\text { Police." }\end{array}$ \\
\hline 7. Syntactical & $\begin{array}{l}\text { S reported selecting ele- } \\
\text { ments from each of the } \\
\text { two paralogs and embed- } \\
\text { ding these elements into } \\
\text { a sentence, phrase or } \\
\text { clause. }\end{array}$ & $\begin{array}{l}\text { Rennet-Quipson: } \\
\text { "Changed Rennet to } \\
\text { Bennet and saw } \\
\text { Quips in Quipson - } \\
\text { thought: Bennet Cerf } \\
\text { Quips on TV." }\end{array}$ \\
\hline
\end{tabular}

to record their answers.

At the conclusion of the learning session, they were again shown each pair. But now they were given $60 \mathrm{sec}$. to report in writing how they attempted to form each association.

\section{Results}

An examination of the verbal reports suggested seven different categories, differing with respect to an apparent underlying continuum of cue complexity. The categories and their rank order are presented in Table 1.

Figure 1 shows the relationship between the rank order of the strategies and the mean number of correct responses per item for 10 trials. Inspection of Fig. 1 reveals a monotonically increasing relationship between the complexity of the associative strategy and correct performance on individual items. A total strategy level score was also obtained for 


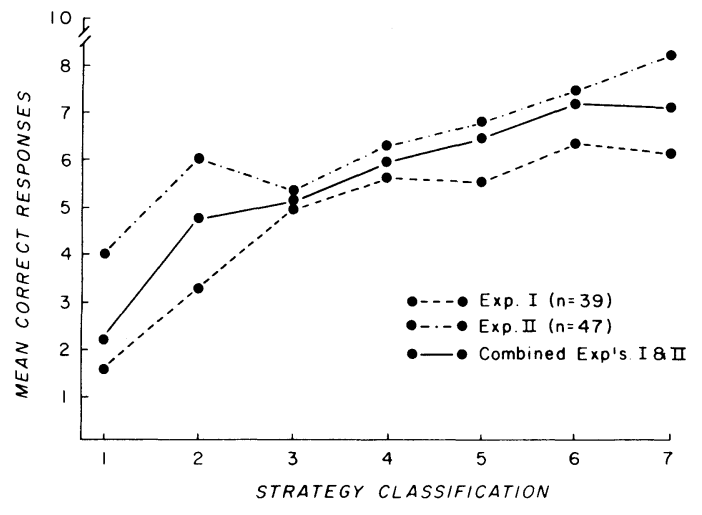

Fig. 1. Mean number of correct responses per item for experiments I and II, and experiments I and II combined as a function of strategy classification.

each S. This score was computed by assigning to each verbal report the appropriate category level and then summing over the eight pairs of items. For example, if the $S$ reported using a Repetition strategy on three pairs ( 3 pairs learned by a 2 level strategy) and a Syntactical strategy on five pairs (5 pairs learned by a 7 level strategy) his total strategy score would be 41. A Spearman rank order correlation coefficient was computed to determine the relationship between total strategy level scores and number of correct responses on eight items in 10 trials. The resulting coefficient $\left(r_{\mathrm{S}}=.62\right)$ was statistically significant beyond the .01 level, and indicates a positive relationship between performance on the learning task and complexity of strategy level reported.

The reliability of the classification scheme was checked by having two judges independently rate all verbal reports. Then a Pearson correlation coeffieient was computed between the separate total strategy level scores obtained for for each individual. The coefficient $(r=.95)$ indicated high agreement between the two sets of independet ratings.

\section{Method}

\section{Experiment II}

Forty-seven students enrolled in an introductory educational psychology class were used as Ss in this experiment. The material and procedure were exactly the same as those employed in experiment I.

\section{Results}

The Ss verbal reports were classified according to the system developed in experiment I. Here again, Fig. 1 shows a monotonically increasing relationship between complexity of strategy level employed and performance on individual items. A Spearman rank order correlation was also computed between total strategy level scores and total number of correct responses. Moreover, this coefficient $\left(r_{\mathrm{S}}=.63\right)$ was significant beyond the .01 level. And the reliability of the classification system was checked, as in experiment I, by having two judges independently rate all verbal reports. The Pearson coefficient $(r=.95)$ between the judges' ratings was similar to that obtained in experiment $I$.

\section{Diseussion}

One of the characteristics of the classification scheme developed in experiment I was the apparent underlying continuum of cue complexity. Assuming this hierarchical relationship among the seven categories, some attempt at quantifying associative strategies appeared reasonable. Therefore, mean number of correct responses per item was plotted against the respective categories to see whether there was any relationship between cue complexity and performance. The resulting plot revealed a monotonically increasing relationship between the ordering of the categories and mean number correct responses. Although this relationship was observed in both experiments, a more stable indication of it is presented in the combined curve in Fig. 1. Thus, the data suggested that an ordinal scale was underlying the dimension of cue complexity, and consequently, that the strategy classification system could be quantified, and that a total strategy level score could be computed for each S.

A Spearman rank order correlation was computed between Ss' total strategy level scores and number of correct responses on the learning task. For both experiments, the coefficient was statistically significant beyond the .01 level, and showed better performance to be associated with the use of higher level strategies. In addition, the results suggest an important way for looking at individual differences in performance on a paired-associate learning task.

The percent frequency of strategy level use for the two experiments combined was also computed: No association $12 \%$, Repetition $11 \%$, Single letter cue $14 \%$, Multiple letter cue 10\%, Word formation 6\%, Superordinate $29 \%$ and Syntactical $18 \%$; and as previously mentioned, the agreement between raters was extremely high. Thus, the data indicate that idiosyncratic verbal reports can be reliably classified, and that while most categories are used with about equal frequency, there is a tendency to use more high level strategies.

In summary, the results of experiments I and II showed that it was possible to categorize Ss' idiosyncratic verbal reports in a reliable and systematic manner, and that such reports provide important data concerning the way in which low M paired-associates are learned.

\section{References}

Eagle, M. \& Leiter, E. Recall and recognition in intentional and and incidental learning. J. exp. Psychol., 1964, 68, 58-63.

Farber, I. E. The things people say to themselves. Amer. Psychologist, 1963, 18, 185-197.

Miller, G. A., Galanter, E., \& Pribram, K. H. Plans and the structure of behavior. New York: Henry Holt and Co., 1960.

Noble, C. E. An analysis of meaning. Psychol. Rev., 1952, 59, 421-430.

Underwood, B. J., \& Schulz, R.. W. Meaningfulness and verbal learning. New York: J. B. Lippincott Co., 1960. Pp. 296-305.

Notes

1. The project report herein was supported by a grant from the U. S. Department of Health, Education, and Welfare, Office of Education, Division of Handicapped Children and Youth.

2. The authors wish to thank Neal VanderVeen for his assistance in conducting this study. 